\title{
Features of communicative competence of specialists in sales of educational organization services
}

\author{
Oksana $\mathrm{Kholina}^{1}$, Elena Kornienko ${ }^{2}$, Tatiana $V$. Buyndyugova ${ }^{3 *}$ \\ ${ }^{1}$ Taganrog Institute named after A. P. Chekhov (branch) RSEU (RINH), Taganrog, Russia \\ ${ }^{2}$ Taganrog Institute of management and economy, Taganrog, Russia \\ ${ }^{3}$ Southern university (IMBL), Rostov-on-Don, Russia
}

\begin{abstract}
The article contains the results of research of features of communicative competence of specialists in sales of services of the educational organization. The paper describes the concept of communicative competence, its main components (motivational, personal, cognitive, behavioral), briefly describes the criteria for the formation of communicative competence, the mechanisms of its development. The results of the analysis of communicative competence of employees who are engaged in the promotion of services within educational institutions are presented: the methods of psychodiagnosis that were used in the course of work are described and the results of the study are summarized. The work also reflects the results of evaluating the level of efficiency in the work of employees in the sphere of sales of educational services, which allowed to identify three groups of employees with high, medium and low efficiency in work. The results of the study confirmed that the effectiveness of sales staff is associated with the level of development of communicative competence.
\end{abstract}

\section{Introduction}

The image, efficiency and competitiveness of any educational organization are always associated with the quality of employees at all levels. In modern conditions, it is especially important to purposefully develop and improve those employees who promote the activities of the educational organization, its paid services.

This direction is highly specialized, there are almost no practical and methodical researches in the field of psychological science on work and development of personnel potential of educational organizations in the sphere of sales and promotion of their services. Because of this, research and development of an effective and targeted management scheme for sales and promotion of services for educational organizations is of particular importance and practical importance.

The task of sales staff in educational organizations is to actively use psychological knowledge and techniques in order to maximize constructive interaction with partners and

\footnotetext{
* Corresponding author: tach 29@mail.ru
} 
potential customers. To do this, they, first of all, must have a high level of development of communicative competence, as they often face problems of mutual understanding in interaction, inability to set up contact with the interlocutor, inconsistent actions, which can lead to the loss of the client.

According to the analysis of various theoretical and methodological studies, it was found that $80-85 \%$ of the employee's success in the field where it is necessary to constantly communicate is determined by the level of communicative competence. The professionally important qualities of sales and service promotion specialists include characteristics that are associated with communicative competence: empathy, attitude in communication, ability to listen, communicative tolerance, ability to filter the content of the message and the General atmosphere of interaction [2].

The content of communicative competence includes communicative knowledge, skills and abilities. Communicative knowledge is information about the concept of "communication", its types, phases, patterns of development. Communication skills (interactive and socially perceptive): the ability to adequately organize the text and Express thoughts, the ability to give and receive feedback, the ability to overcome barriers to communication. Communicative abilities - this individual psychological characteristics of a personality that meet all the requirements of communicative activities and ensure its implementation.

Among the components of the communicative competence of a sales person in an educational organization can be identified [1]:

- motivational and personal: motives of communication, empathy, tolerance, adaptability, self-esteem, etc.;

- cognitive: a system of communicative actions based on the knowledge of communication, which allows you to freely navigate and act within the cognitive space (perception, analysis, modeling and transmission of information);

- behavioral: skills and abilities of professional communication, its styles and ways.

The main task of the professional communicative skills of the employee in sales in an educational institution - the achievement of understanding. In addition, there are a number of different tasks in the development of communicative competence:

- receipt or communication of information for the qualitative performance of functional duties;

- management of customer behavior, their attitude to the features of the product or service;

- satisfaction of the Manager's need for communication [2].

Criteria of formation of communicative competence - high level of development of skills of team work, self-control of emotions in communication and interaction, motivational and valuable attitude to interaction in activity, competent oral and written speech, orientation to cooperation (ability to suppress aggression, hostility to people; to level feeling of hostility; presence of tact), also ability to transfer knowledge, experience, to help growth of colleagues [3].

At the heart of improving the level of communicative competence of sales staff in the educational organization are the mechanisms:

- involvement of managers in the research process of their competence, the search for the most effective ways to interact with a potential client;

- emotional involvement in the process of work, which forms a positive system of relationships in the team;

- development of self-knowledge skills and knowledge of others;

- awareness of their individual style in sales and individual psychological characteristics as a specialist in this field [4].

James F. angel, Roger F. Blackwell and Paul W. Miniard, argue that success in sales depends not so much on the temperament, age and appearance of the seller, but more on the 
level of communicative skill and motivation, interaction during the purchase. These characteristics are developed in the framework of training and practice [2].

R. A. Schnappauf notes that the technology of competent active sales should be based on the development of communicative competence of the employee [6].

Hisrich R., Jackson R. has noted that effective staff of sales is distinguished by a highly developed effective communicative competence and interaction skills [3].

$\mathrm{V}$. Vetrogradov notes that not only good knowledge of products should be in the sales staff, but also they should have the personal qualities possessed by psychologists, consultants, coaches [2].

In the works of E.V. Vaskin and V.V. Usov, it is noted that effective sales professionals have: a high level of behavior regulation and a developed communicative potential, a high level of neuropsychic stability, adequate perception of reality, adequate self-esteem; rapid establishment of contacts with others, low conflict, good adaptation to new conditions of activity [5].

Thus, communicative competence is always an experience of constructive interaction with others, which is necessary for successful implementation in a professional environment. In modern society, all sales activities are based on well-constructed communication processes. Interpersonal communications determine the success of each stage of sales professionals. From $50 \%$ to $90 \%$ of sales specialist's working time is connected with communication.

Consequently, the communicative competence of a sales specialist is the main tool for solving professional problems, since it is the words that act as a tool in the interaction with customers.

The problem of communication, communicative abilities and, in particular, the abilities of managers in the sphere of sales systematically and adequately describes the methodology of interpersonal communication, communication in the works of K. A. AbulkhanovaSlavske, B. D. Parygina; in the works of B. G. Ananyev, G. M. Andreeva, A. A. Volumes V. N. Kunicina, A. A. Leontiev - the analysis of communicative activities. The research of A. A. Verbitsky, I. A. Zimnaya, M. I. Lukyanova, I. I. Revyakina, V. A. Yakunin is Devoted to the development of communicative competence of specialists. Communications in sales are devoted to the work of D. Schultz, S. Tannenbaum, R. Lauterborn, John. Barnet, S. Moriarty. All these works are of great theoretical and practical importance, but the study of the development of communicative competence of sales professionals in the educational organization in the context of modern conditions requires special attention. This led to the choice of topic and relevance of the study.

The purpose of the study is to analyze the communicative competence of employees who are engaged in the promotion of services within educational organizations.

The object of the study: employees of educational organizations that are engaged in the promotion of educational services and interaction with potential customers at the stage before the conclusion of the contract (64 people: women and men aged 22 to 40 years, with higher education and experience in sales and promotion of services from 1 to 6 years).

Subject of research: components of communicative competence of employees of educational organizations, which are engaged in the promotion of educational services and interaction with potential customers at the stage before the conclusion of the contract.

The hypothesis of the study: the effectiveness of the staff of educational organizations that are engaged in the promotion of educational services and interaction with potential customers at the stage before the conclusion of the contract is associated with the level of development of its communicative competence: the higher the level of competence, the higher its efficiency in work.

Research problem:

- measure the level of communicative competence; 
- analyze the level of efficiency of employees with different levels of communicative competence;

- to identify the links between the level of communicative competence and the effectiveness of activities in the field of promotion of services and interaction with potential customers at the stage before the conclusion of the contract;

- to identify differences in the level of communicative competence of effective and inefficient employees of educational organizations.

The study used the following methods and techniques:

1) to assess the communicative competence of the methodology:

- communicative and social competence;

- communicative tolerance (V. V. Boyko);

- emotional barriers in interpersonal communication (V. V. Boyko);

- personal differential;

2) to assess the effectiveness of service promotion:

- questionnaire for sales managers (A. A. Mishin);

- methods of assessing the quality of the seller.

3) methods of mathematical statistics: to identify relationships correlation analysis (Spearman criterion); to identify differences Mann-Whitney criterion.

\section{Description of results and discussion}

The research procedure contains a number of stages.

The first is a survey of respondents on the methods of diagnosis of communicative competence and effectiveness of the sales specialist.

The second is data processing and interpretation.

The third - to identify the relationship between the effectiveness of sales staff and the level of development of their communicative competence, also at this stage, differences in the features of the communicative competence of sales staff with different levels of efficiency in the work were identified.

1) According to the questionnaire for sales managers, it was possible to assess various aspects related to the assessment of the effectiveness of their work in this area by the sellers themselves:

- the most significant reasons for work in this area, highlighted by respondents - "like to communicate with people" (89\%), "believe that the necessary money can earn only in sales" $(82 \%)$, "like sales as a field of activity" (79\%);

- the most important tasks in the work of the respondents called "improving the quality of customer service" (86\%) and "increasing the number of retail sales" $(93 \%)$;

- as for the motivation of work in sales, employees note: "the increase in the number of buyers" (93\%), "the increase in the number of newly applied buyers" (79\%);

- $86 \%$ of employees believe in the offered educational services, their quality and efficiency, which is a serious "bonus" in the effectiveness of the seller.

2) Employees in the study had to list the characteristics of the proposed service groups, which allowed to talk about the level of their awareness, which in $61 \%$ of cases is at the average level (61\% of employees were able to list the main characteristics of services from 7-8 groups, but could not describe in detail their advantages and disadvantages, structure features). It was also found that $31 \%$ of specialists can present the needs of the client, but can not describe them in detail, to recognize the specific conditions. Only $9 \%$ of specialists were able to formulate a portrait of a typical client, describing his needs, what services he needs, on what terms.

3 ) in Order to get a complete picture of the prospects and opportunities of specialists in the field of sales of educational services, with the help of personnel services, a large number 
of indicators were collected and a sufficiently extensive analysis (also taking into account the data of the marketing Department) was carried out taking into account the average for the last six months.

The average performance and professionalism calculations for the sample of sales professionals who participated in the study are presented in table 1.

Table 1. Indicators of efficiency and professionalism of specialists in the sphere of sales of educational services

\begin{tabular}{|c|l|c|}
\hline № & \multicolumn{1}{|c|}{ Figure } & Average value \\
\hline 1 & Performance indicator & 53,8 \\
\hline 2 & Production rating & 40 \\
\hline 3 & Status rating & 69,2 \\
\hline 4 & Profitability & 7,8 \\
\hline 5 & Level of professional freedom & 410 \\
\hline 6 & Professionalism & 34,2 \\
\hline
\end{tabular}

The data in table 1 showed that the overall efficiency is at the average level, as well as profitability, the status rating is above average, and professionalism is lower. This suggests that employees need targeted and targeted development to improve performance.

All the data described above allowed us to divide specialists into groups with different levels of efficiency in their work:

- 1st group with a high level of efficiency (9\%): specialists are active in work, easily establish contact with the client, do not let the client without buying the service. They are able to get along with people, and not to the detriment of the result and other professionals, show consistently high results, understand the motives, needs of customers, is constantly evolving, easily solves complex situations in interaction, easily advises on issues related to the services provided;

- 2nd group with an average level of efficiency (63\%): employees have achievements, they can train a new employee. He understands that his income depends on the total number of clients, their satisfaction, but he sometimes considers the client as an opponent who must be defeated. He needs to analyze his professional behavior more often and identify areas for development. He is quite clearly versed in his motivation, in all the needs of the client, is fully informed about the services, but does not always show initiative, activity, creativity.

- Group 3 with a low level of efficiency (28\%): the employee shows a minimum of initiative, analysis of their work. He needs to learn the ability to prioritize work, develop skills to respond to objections, the ability to establish contact, to find a common language with the client. He does not try to understand the needs of the client, does not want to help the client to learn more information about the services.

Statistical analysis confirmed significant differences differences between employees in the sphere of sales with different levels of efficiency: in the manifestation of professionalism $\left(\mathrm{U}_{\mathrm{emp}}=0,106\right)$, efficiency $\left(\mathrm{Uemp}_{\mathrm{e}}=0,202\right)$, the level of profitability $\left(\mathrm{U}_{\mathrm{emp}}=0,129\right)$, ranking $\left(\mathrm{Uemp}_{\mathrm{e}}=0,101\right)$. Therefore, all the efforts that employees make, their knowledge, skills differ at different levels of efficiency in the activity.

After that, the peculiarities of communicative competence of sales staff with different levels of professional efficiency were highlighted:

1) high communicative competence is more pronounced in employees with a high level of efficiency: they are sociable, they have a highly developed logical thinking, they control their emotional manifestations in interaction, they have a balance between emotions and rationality in behavior. 
2) employees with a high level of efficiency have a high level of communicative tolerance;

3) emotional barriers in communication and interaction are also lower for those sales staff who show greater efficiency in work, but in some cases can be observed: the dominance of negative emotional manifestations; unwillingness to communicate with customers on an emotional basis.

4) employees with a high level of efficiency accept themselves as a person, satisfied with themselves, behavior. They also clearly understand the "pros" and "cons" of their character and behavior, they are characterized by a fairly high level of self-esteem; they have selfesteem, expressed self-confidence, independence, they tend to rely only on their own strength in difficult working situations. They are characterized by a high level of creative, intellectual and General activity, a high level of understanding of emotions. They easily make contact with people.

\section{General conclusion}

In order to test the hypothesis of the relationship of communicative competence and effectiveness in communication, a correlation analysis was carried out. The connections between the components of communicative competence and efficiency in work were revealed: the higher the level of self-esteem, sociability, emotional stability, self-control, communicative tolerance, extroversion and the lower the level of emotional barriers, the higher the efficiency in work. Thus, the hypothesis that the effectiveness of the activities of employees of educational organizations that promote the services of educational organizations and interaction with potential customers at the stage before the conclusion of the contract is associated with the level of development of its communicative competence: the higher the level of competence, the higher its efficiency in work - confirmed.

Analysis of the development of communicative competence of sales staff with different levels of professional efficiency showed the following. Qualities that characterize employees as those who have expressed communicative competence are represented in employees with high efficiency in work. The higher the efficiency of sales staff, the higher the level of communicative tolerance. Employees with an average and high level of efficiency do not experience emotional difficulties in interaction and communication. It was also found that the higher the efficiency in the work, the higher the activity, willpower and extroversion.

\section{References}

1. I.V. Androsova, Molodoj uchenyj. 9, 498-500 (2015) 2014)

2. A.A. Bodalev, Psihologija obshhenija (Institut prakticheskoj psihologii, Moscow,

3. A. Druzhinin, A. Zamulin, Trening prodazh (Rech', St. Petersburg, 2014)

4. E.V. Rudenskij, Osnovy psihotehnologij obshhenija menedzhera (INFRA-M, Moscow, 2014)

5. A. Hodakov, Psihologija uspeshnyh prodazh (Rech', St. Petersburg, 2013)

6. R. Shnappauf, Praktika prodazh (Interjekspert, Moscow, 2012) 